\title{
PENYULUHAN KESEHATAN DAN SKRINING HBsAg SEBAGAI UPAYA PENGENDALIAN HEPATITIS
}

\section{HEALTH EDUCATION AND HBsAg SCREENING FOR HEPATITIS CONTROLLING}

\author{
${ }^{1)}$ Adhi Permana, ${ }^{2}$ Sheilla Yonaka Lindri, ${ }^{3)}$ Mitayani Purwoko \\ ${ }^{1}$ Departemen Ilmu Penyakit Dalam, ${ }^{2}$ Departemen Ilmu Kesehatan Masyarakat, ${ }^{3}$ Departemen Biologi \\ Fakultas Kedokteran Universitas Muhammadiyah Palembang \\ Jl. KH Balqhi (Talang Banten), 13 Ulu, Palembang \\ email: adhipermana27@gmail.com
}

\begin{abstract}
ABSTRAK
Hepatitis adalah penyakit peradangan pada hati. Pada tahun 2013, prevalensi HbsAg di Indonesia sebesar 7,2\%. Dinas Kesehatan Kabupaten Banyuasin belum melaporkan telah melakukan program pengendalian Hepatitis di wilayahnya. Desa Muara Sungsang terletak sangat dekat dengan Pelabuhan Tanjung Api-Api Sumatera Selatan yang menjadi pintu masuk dari provinsi lain. Hal ini membuat Desa Muara Sungsang menjadi rentan menjadi daerah penularan penyakit menular. Salah satu upaya yang digalakkan sebagai aksi advokasi pencegahan penularan Hepatitis adalah pendidikan kesehatan dan deteksi dini. Tujuan kegiatan pengabdian kepada masyarakat ini ada dua yaitu menyebarkan informasi mengenai penyakit Hepatitis serta melakukan penapisan infeksi virus Hepatitis B di Desa Muara Sungsang, Kabupaten Banyuasin, Sumatera Selatan. Pendidikan kesehatan dilakukan dengan pemberian penyuluhan pada kelas besar. Penapisan HbsAg dilakukan dengan menggunakan rapid test kit dengan menggunakan darah vena untuk memperoleh plasma darah. Kegiatan ini berhasil menemukan warga dengan HBsAg positif yang menjadi indikator keberhasilan kegiatan. Sebanyak 6 dari 26 peserta yang bersedia diperiksa darahnya dinyatakan HBsAg positif. Saran, pemerintah dan institusi pendidikan perlu meningkatkan upaya menyebarkan informasi dan pengendalian hepatitis bagi warga Desa Muara Sungsang.
\end{abstract}

Kata kunci : Hepatitis, Pendidikan Kesehatan, Hbsag

\section{ABSTRACT}

Hepatitis is an inflammation disease of the liver. Prevalence of HBsAg infection in Indonesia in 2013 was 7.2\%. Public Health Office of Banyuasin District did not report any action on Hepatitis controlling inside their area. Muara Sungsang Village is located near Tanjung Api-Api Sea Port of South Sumatera which is the port d'entry of peoples from other states. This situation makes Muara Sungsang Village become vulnerable to contagious diseases. Some efforts to do that are health education and early detection. The aim of this community service were to spread the information about Hepatitis and screening of Hepatitis infection in peoples of Muara Sungsang Village, Banyuasin, South Sumatera. Health education for big group was done and the screening was done using rapid test kit. The indicator of success of this action is to find the positive HBsAg peoples in Muara Sungsang Village. This screening found 6 out of 26 peoples were HBsAg positive. Government and institutions of health education should increase the efforts to spread the information of Hepatitis and surveilance system to prevents Hepatitis infection.

Keywords: Hepatitis, Health Education, Hbsag

Submited : 26 Juli 2018 Revision : 8 November 2018 Accepted: 16 November 2018

\section{PENDAHULUAN}

Hepatitis adalah penyakit peradangan pada hati. Penyakit ini dapat disebabkan oleh virus, bakteri, dan parasit. Namun hepatitis dengan penyebab virus adalah yang paling banyak terjadi. Infeksi virus hepatitis $B(\mathrm{HBV})$ dapat didiagnosis 
setelah ditemukannya hepatitis B surface antigen (HbsAg) oleh Blumberg pada tahun 1965 (Chan \& Wong, 2012). Hasil Riset Kesehatan Dasar tahun 2013 menemukan prevalensi HbsAg di Indonesia sebesar 7,2\% (Kemenkes RI, 2013). Endemisitas HBV di Indonesia termasuk menengah hingga tinggi dengan kisaran 2,5-10\% untuk angka kejadian HBsAg. HBV diklasifikasikan menjadi 9 genotipe (A, B, C< D, E, F, G, H, dan J). Subgenotipe yang paling banyak di Indonesia adalah HBV B3 dan HBV C1 (Yano, Utsumi, Lusida, \& Hayashi, 2015).

Pemerintah Indonesia melalui Kementerian Kesehatan Republik Indonesia mencanangkan program Eliminasi Penularan Hepatitis B dari ibu ke anak pada tahun 2020 dan Eliminasi Hepatitis C pada tahun 2030. Salah satu upaya yang digalakkan sebagai aksi utama adalah peningkatan kesadaran dan deteksi dini (Biro Komunikasi dan Pelayanan Masyarakat Kemenkes RI, 2016).

Desa Muara Sungsang terletak di dekat Pelabuhan Tanjung Api-Api Sumatera Selatan yang menjadi pintu masuk dari Provinsi Bangka Belitung ke Provinsi Sumatera Selatan. Daerah di sekitar pintu masuk biasanya akan menjadi daerah pertama penularan penyakit menular, salah satunya Hepatitis B. Selain itu, dalam laporan Dinas Kesehatan Banyuasin belum ada laporan kegiatan terkait aksi advokasi Hepatitis di wilayahnya. Padahal sejak tahun 2012 Kementerian Kesehatan Republik Indonesia telah mengeluarkan Pedoman Pengendalian Hepatitis Virus sebagai panduan bagi petugas kesehatan (Kemenkes RI, 2012).

Oleh karena itu, warga Desa Muara Sungsang perlu mendapat pendidikan kesehatan terkait penyebaran penyakit menular. Tujuan kegiatan pengabdian kepada masyarakat ini adalah memberikan pendidikan kesehatan mengenai penyakit
Hepatitis serta melakukan skrining $\mathrm{HbsAg}$ sebagai indikator infeksi virus Hepatitis B pada warga Desa Muara Sungsang, perangkat Desa Muara Sungsang, serta staf Puskesmas Tanjung Api-Api.

\section{METODE}

Solusi untuk mengatasi situasi di Desa Muara Sungsang terkait Hepatitis B dilakukan dengan dua langkah yaitu:

1. Pendidikan masyarakat. Target kegiatan ini adalah 50 orang. Langkah ini berupa pemberian informasi mengenai Hepatitis dalam bentuk penyuluhan massal oleh dokter spesialis penyakit dalam selama kurang lebih 20 menit dan diikuti sesi tanya jawab selama 10 menit. Sebelum penyuluhan, peserta diminta mengisi lembar pertanyaan sebanyak 5 soal yang berisi pertanyaan tentang Hepatitis. Pemberian materi diberikan melalui media power point.

2. Pemeriksaan HbsAg dengan menggunakan rapid test kit. Target kegiatan ini adalah 50 orang. Pengambilan darah dilakukan oleh analis terlatih dengan cara mengambil darah vena sebanyak 3 cc lalu ditampung dalam tabung darah mengandung EDTA. Tabung darah kemudian diputar di dalam sentrifus selama 10 menit agar terbentuk plasma. Strip rapid test dicelupkan ke dalam plasma selama 5-10 detik sampai plasma terserap. Lalu hasilnya dibaca setelah 2 menit. Hasil positif akan memberikan gambaran 2 garis pada strip, dan bila hasil negatif akan memberikan gambaran 1 garis pada strip.

Kegiatan dilakukan di Puskesmas Tanjung Api-Api, Kabupaten Banyuasin, Sumatera Selatan dengan indikator keberhasilan yaitu menemukan warga dengan $\mathrm{HBsAg}$ positif. 


\section{HASIL DAN PEMBAHASAN}

Penyuluhan mengenai Hepatitis kepada warga Desa Muara Sungsang berjalan dengan lancar. Peserta terdiri dari warga, perwakilan perangkat desa, serta staf Puskesmas setempat. Warga menunjukkan antusiasme yang cukup baik sepanjang acara penyuluhan. Jumlah peserta penyuluhan tidak mencapai target 50 orang. Hal ini terkait jarak Puskesmas yang jauh dari rumah warga sehingga kemungkinan warga enggan datang ke Puskesmas.

Sebelum penyuluhan warga dan perangkat desa diminta menjawab lima pertanyaan terkait hepatitis. Hasil jawaban para warga dirangkum dalam tabel 1 .

Tabel 1. Jawaban Tes Sebelum Penyuluhan

\begin{tabular}{|c|c|c|}
\hline No. & Pertanyaan & Jawaban warga \\
\hline 1 & $\begin{array}{l}\text { Hepatitis } r \text { adalah } \\
\text {.....(penyakit radang } \\
\text { hati) }\end{array}$ & $\begin{array}{l}\text { Benar: } 8 \text { orang }(61,5 \%) \\
\text { Salah: } 5 \text { orang }(38,5 \%)\end{array}$ \\
\hline 2 & $\begin{array}{l}\text { Hepatitis disebabkan } \\
\text { oleh .....(virus) }\end{array}$ & $\begin{array}{l}\text { Benar: } 2 \text { orang }(15,4 \%) \\
\text { Salah: } 11 \text { orang }(84,6 \%)\end{array}$ \\
\hline 3 & $\begin{array}{l}\text { Penyakit Hepatitis } \\
\text { ada..... macam. (5) }\end{array}$ & $\begin{array}{l}\text { Benar: } 0 \text { orang }(0 \%) \\
\text { Salah: } 13 \text { orang }(100 \%)\end{array}$ \\
\hline 4 & $\begin{array}{l}\text { Hepatitis yang timbul } \\
\text { akibat memakan } \\
\text { makanan yang tidak } \\
\text { bersih atau minum } \\
\text { dari sumber air yang } \\
\text { tercemar adalah } \\
\text {...(hepatitis A) }\end{array}$ & $\begin{array}{l}\text { Benar: } 5 \text { orang }(38,5 \%) \\
\text { Salah: } 8 \text { orang }(61,5 \%)\end{array}$ \\
\hline 5 & $\begin{array}{lr}\text { Hepatitis } & \text { yang } \\
\text { dicegah } & \text { dengan } \\
\text { pemberian } & \text { imunisasi } \\
\text { pada } & \text { bayi } \\
\text { adalah...(hepatitis B })\end{array}$ & $\begin{array}{l}\text { Benar: } 5 \text { orang }(38,5 \%) \\
\text { Salah: } 8 \text { orang }(61,5 \%)\end{array}$ \\
\hline
\end{tabular}

Keterangan: jawaban pertanyaan yang benar tercantum dalam kurung dengan huruf tebal

Berdasarkan data dalam tabel 1, dapat dinyatakan bahwa sebagian besar warga belum memahami apa itu hepatitis karena 4 dari 5 pertanyaan lebih didominasi oleh jawaban yang salah. Kelemahan kegiatan ini adalah tim tidak melakukan penyebaran soal tes pasca penyuluhan karena warga sudah banyak yang pulang sehingga tidak dapat diukur perubahan skor pra dan pasca penyuluhan.
Proses pemeriksaan HbsAg dilakukan setelah penyuluhan dengan jumlah peserta yang bersedia diperiksa sebanyak 26 orang. Hal ini tidak sesuai dengan target awal kegiatan yaitu dapat melakukan pemeriksaan HbsAg pada 50 orang.

Dari 26 peserta yang bersedia diperiksa darahnya, ditemukan 6 peserta dengan hasil positif $(23,08 \%)$. Hal ini menunjukkan bahwa 6 orang tersebut memiliki antigen permukaan virus Hepatitis B. Semua peserta yang ditemukan $\mathrm{HBsAg}$ positif mengaku tidak pernah mengalami gejala seperti kuning, demam, mual muntah. Hal ini dapat terjadi karena gejala infeksi hepatitis B dan sembuh tidaknya tergantung dari usia pada saat terinfeksi (Lusida \& Yano, 2016). Jika terinfeksi pada saat anak-anak maka jarang yang memiliki gejala, sementara jika terinfeksi saat dewasa maka ada kemungkinan $70 \%$ tidak menunjukkan gejala dan $30 \%$ menunjukkan gejala kuning. HbsAg muncul di dalam serum penderita pada 2-10 minggu setelah terinfeksi virus Hepatitis B dan akan menghilang setelah 4-6 bulan. Adanya HBsAg yang menetap setelah 6 bulan menunjukkan adanya infeksi kronis Hepatitis B. Skema ditampilkan dalam gambar 3 (Trépo, Chan, Lok, \& Lyon, 2014).

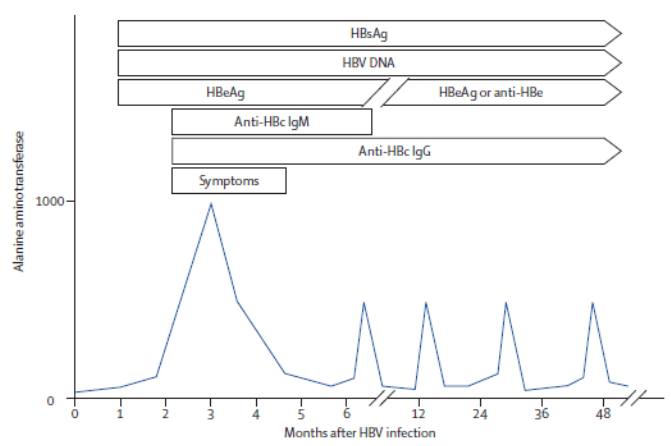

Gambar 3. Skema biomarker infeksi Hepatitis B kronis. Tampak pada gambar bahwa kadar HBsAg akan menetap setelah 6 bulan (Sumber: Trépo, Chan, Lok, \& Lyon, 2014) 
Peserta yang ditemukan $\mathrm{HBsAg}$ positif kemudian mendapat edukasi dan resep dari salah satu tim pengabdian yang berprofesi sebagai dokter spesialis penyakit dalam. Mereka diedukasi mengenai cara menjaga kesehatan hati agar tidak jatuh ke kondisi hepatitis fulminan. Mereka juga diminta melakukan pemeriksaan darah di laboratorium rumah sakit untuk memeriksakan diri lebih lanjut.

Jumlah warga yang memiliki kadar HbsAg positif dalam kegiatan ini persentasenya lebih tinggi bila dibandingkan dengan beberapa penelitian terdahulu. Sebuah penelitian yang melakukan skrining infeksi Hepatitis B pada ibu hamil di Malang menemukan hasil positif sebesar 1\% (Mustika \& Hasanah, 2018). Sebuah penelitian pada tenaga kesehatan di kota Sulawesi Selatan menemukan 6,2\% dari responden memiliki HBsAg positif (Wijayadi et al., 2018).

Berdasarkan analisis SWOT dalam buku Pedoman Pengendalian Hepatitis Virus, dinyatakan bahwa kelemahan Indonesia adalah sistem surveilans hepatitis belum berjalan dengan baik, kualitas sumber daya manusia masih kurang, serta sarana untuk diagnosis di laboratorium Puskesmas masih kurang. Puskesmas Tanjung Api-Api sebagai pusat kesehatan masyarakat di Desa Muara Sungsang sebaiknya perlu meningkatkan upaya surveilans untuk penyakit Hepatitis B, karena tidak semua penderita menunjukkan gejala pada saat terinfeksi. Telah adanya sarana laboratorium yang memadai dan adanya SDM analis di Puskesmas Tanjung Api-api akan sangat membantu proses surveilans ini.

Pemerintah perlu melakukan penyebaran informasi mengenai penyakit Hepatitis. Institusi pendidikan kesehatan dan kedokteran juga perlu membantu upaya pemerintah dengan mengintegrasikan upaya penyebaran informasi mengenai penyakit Hepatitis dengan kegiatan di institusi pendidikan masing-masing. Upaya pengabdian kepada masyarakat selanjutnya yang dapat dilakukan adalah dengan pemeriksaan HbsAg dan Anti HBS di laboratorium rumah sakit kepada warga yang terinfeksi virus Hepatitis B dan diminta kontrol secara rutin untuk melihat perkembangan kesehatan mereka.

\section{SIMPULAN}

Pengetahuan warga Desa Muara Sungsang mengenai penyakit Hepatitis masih kurang. Penyuluhan mengenai hepatitis yang telah diberikan menjadi salah satu cara penyampaian informasi awal bagi warga bahwa penyakit Hepatitis menular dan mereka merupakan salah satu masyarakat yang berisiko tertular Hepatitis.

Kesadaran warga untuk memeriksakan diri pada saat skrining HBsAg sudah cukup baik. Indikator suksesnya kegiatan ini adalah berhasil menemukan warga dengan HBsAg positif dan kegiatan ini menemukan cukup banyak warga yang pernah terinfeksi Hepatitis B namun tanpa gejala.

\section{UCAPAN TERIMA KASIH}

Kepada Kepala Desa Muara Sungsang dan seluruh aparat desa serta Kepala Puskesmas Tanjung Api-Api Banyuasin dan seluruh staf atas bantuan dan ijin dalam pelaksanaan kegiatan pengabdian kepada masyarakat. Kementerian Riset, Teknologi, dan Pendidikan Tinggi atas pemberian hibah Pengabdian Kepada Masyarakat tahun 2018.

\section{DAFTAR PUSTAKA}

Biro Komunikasi dan Pelayanan Masyarakat Kementerian Kesehatan Republik Indonesia. (2016). Sebagian Besar Kematian Akibat Hepatitis Virus Berhubungan Dengan Hepatitis B dan C Kronis. Jakarta: Kementerian Kesehatan Republik Indonesia.

Chan, HLY. Dan Wong, VWS. (2012). Hepatitis B. Dalam TD Boyer, M.P. 
Manns, dan A.J. Sanyal (Ed.), Zakim and Boyer's Hepatology 6th edition. Elsevier: 540-563.

Kementerian Kesehatan Republik Indonesia. (2013). Riset Kesehatan Dasar. Jakarta: Kementerian Kesehatan Republik Indonesia.

Kementerian Kesehatan Republik Indonesia. (2012). Pedoman Pengendalian Hepatitis Virus. Jakarta: Kementerian Kesehatan Republik Indonesia.

Lusida, M. I., \& Yano, Y. (2016). Current hepatitis B virus infection situation in Indonesia and its genetic diversity. World Journal of Gastroenterology.22(32), 7264-7274.

Mustika, S., \& Hasanah, D. (2018). Prevalensi Infeksi Hepatitis B pada Ibu Hamil di Malang. Jurnal Kedokteran Brawijaya. 30(1), 76-80.

Trépo, C., Chan, H. L. Y., Lok, A., \& Lyon, H. C. De. (2014). Hepatitis B virus infection. The Lancet. 384: 2053-2063.

Wijayadi, T., Sjahril, R., Turyadi, Ie, SI., Wahyuni, R., Pattelongi, I., et al. (2018). Seroepidemiology of HBV infection among health-care workers in South Sulawesi, Indonesia. BMC Infectious Diseases. 18(279):1-11.

Yano, Y., Utsumi, T., Lusida, M. I., \& Hayashi, Y. (2015). Hepatitis B virus infection in Indonesia. World Journal of Gastroenterology.21(38), 10714 10720. 